эластичными пулями сферической формы, с учетом положений теоретической механики и высокоскоростного удара, дано обоснование механизма образования указанных ран. Установлено, что выходная огнестрельная рана на коже начинает формироваться до контакта шара с ней, непосредственный контакт пули с краями выходной огнестрельной раны будет происходить только при прохождении между уже образовавшимися разрывами на коже, с последующим инерционным их расширением и увеличением в размерах. В случаях, когда участок расположения исходной огнестрельной раны плотно прилегает к препятствию (плотная одежда, предметы обстановки), в месте контакта препятствия с участком округлой формы выпячивания поверхности тела, будут образовываться дефект кожи и пасочек ссадины, за счет действия огнестрельного снаряда на кожу изнутри при статическом положении преграды.

Ключевые слова: морфология повреждений, огнестрельная травма, выходная рана.

\title{
MORPHOLOGICAL STUDY OF THE MECHANISM OF FORMATION OF THE INITIAL GUNSHOT WOUND, SUBJECT TO THE PROVISIONS OF THEORETICAL MECHANICS
}

\author{
Mikhaylenko O. V., Grinchishina O. V.
}

Summary. Background. According to most authors, the mud pies abrasion with gunshot damage is a destroyed epidermis at the edges of the skin defect, which forms the ball onto the path of penetration in the thickness of the layers of the skin and body tissue. As shown by their own expert practice, the flaps of epidermis always have a triangular shape, and their tops facing in the direction of the skin defect and the core - to-perimeter the abrasion ring, in this case, there is no reduction of the thickness of the surface of the dermis in the region the abrasion ring. Therefore, no complete explanation of the stages and mechanism of formation of the abrasion ring around the edges of the skin defect at the entrance gunshot gunshot wound in contact with the projectile at right angles. Objective. The objects of the study were entrance gunshot wounds, which were formed as a result of shots with bullets of 9 mm caliber, obtained from archival material of the Bureau of forensic medical examination and experimentally obtained gunshot injuries of blocks of sculptural plasticine $9 \mathrm{~mm}$ with elastic spherical shells. Methods. Research methods were applied: morphological, medical-criminalistic, visual, analytical and comparative. Conclusion. Data of theoretical mechanics were used to estimate the mechanics of skin destruction. By studying the morphological features of the exit gunshot wounds, which were formed as a result of shots with bullets of caliber $9 \mathrm{~mm}$, and experimental damage to blocks of plasticine caused by $9 \mathrm{~mm}$ elastic bullets of spherical shape, taking into account the provisions of theoretical mechanics and high-speed impact, the substantiation of the mechanism of formation of these wounds. It is established that the exit gunshot wound on the skin begins to form before the contact of the ball with it, the direct contact of the bullet with the edges of the exit gunshot wound will occur only when passing between the already formed ruptures on the skin, followed by their inertial expansion and increase in size. In cases where the site location of the original gunshot wound fits snugly to the obstacle (thick clothing, furnishings), at the point of contact with the obstacle site rounded protrusion of the body surface, will form a skin defect and pasochek abrasion, due to the action of the fire projectile on the skin from the inside at a static position of the barrier.

Key words: morphology of injuries, gunshot wound, exit wound.

УДК 612.12-001.45:340.624

\section{ВИЯВЛЕННЯ МОРФОЛОГІЧНИХ ОСОБЛИВОСТЕЙ ЧАСТОК МЕТАЛІВ, ЗГОРІЛИХ І НАПІВЗГОРІЛИХ ПОРОШИНОК, ПРОДУКТІВ РОЗКЛАДАННЯ ІНІЦІЮЮЧОГО ВИБУХОВОГО СКЛАДУ КАПСУЛЯ ПРИ ПОСТРІЛАХ ІЗ 9 ММ ПІСТОЛЕТІВ 3 ПРЯМОКУТНОЮ І ПОЛІГОНАЛЬНОЮ ФОРМАМИ НАРІЗІВ СТВОЛА 3 ВИКОРИСТАННЯМ РАСТРОВОЇ СКАНУЮЧОЇ ЕЛЕКТРОННОЇ МІКРОСКОПІЇ}

\section{(C) Я. В. Чихман}

\author{
Національна медична академія післядипломної освіти імені П. Л. Шупика
}

Резюме. В роботі наведені результати експериментального дослідження з використанням растрової скануючої електронної мікроскопії морфологічних особливостей часток металів, згорілих і напівзгорілих порошинок, продуктів розкладання ініціюючого вибухового складу капсуля при пострілах із 9 мм патронів до пістолету «Форт 17» 3 прямокутною i «Glok 19» полігональною формами нарізів ствола. Проведене дослідження надає можливість чітко візуалізувати виявлені за допомогою рентгенфлуоресцентго спектрального аналізу частки металу, що утворюються при русі кулі по каналу ствола зброї; диференціювати штучно спалені порошинки з їх подальшим нанесенням на поверхню ділянки вогнепального ушкодження (пошкодження) з тими порошинками, що утворились при проведенні пострілу із вогнепальної зброї з близької дистанції. Також встановлено, що колір кіптяви визначає капсульний склад продуктів пострілу: сірі порошинки розташовані ближче до запального отвору гільзи і вони максимально вкриті капсульним складом, що розкладається при його вибуху та підпалюванні порохового заряду. Жовті порошинки розташовуються ближче до кулі, причому, на їх поверхні продуктів розкладання капсульного складу вкрай мало, що не змінює колір порошинок, на які діяло полум'я (термічна дія).

Ключові слова: судово-медична експертиза, фактори, що супроводжують постріл, растрова скануюча електронна мікроскопія.

ВСТУП.

Одним із актуальних в експертизі вогнепальних пошкоджень є визначення продуктів згоряння заряду чи 
факторів, що супроводжують постріл [1,2]. Їх дослідженням присвячена значна кількість як вітчизняних, так і закордонних робіт.

Зокрема, Губєєвою Е. Г. (2008-2009) [] за допомогою мікрозондового рентгеноспектрального аналізу було виявлено ознаки, що дозволяють визначати зони близької дистанції пострілу не повністю згорілих частинок пороху. Отримані нею дані сприяють підвищенню ефективності криміналістичних досліджень 3 метою встановлення марки порохового метального заряду і особливостей використаних боєприпасів (патронів) для визначення моделі вогнепальної зброї.

Куценко К. І., Макаров І. Ю. (2013), досліджуючи особливості виходу і розповсюдження продуктів пострілу холостими і травматичними патронами із 9 мм пістолета МР-79-9ТМ шляхом використання фотографічного методу у прямій і бічній проекціях спромоглися зафіксувати траєкторії часточок пороху, що горіли, і визначити їх кількість. Окрім цього, для визначення граничної відстані продуктів пострілу різними пістолетами, авторами було визначене їх розповсюдження і відкладання на горизонтальних мішенях (так званих «слідових доріжках»). Отже, Куценко К. И., Макаров І. Ю. (2013) визначили склад і остаточні відстані розповсюдження продуктів пострілу штатними холостими і травматичними патронами із пістолету МР-79-9ТМ. Вони дійшли висновку, що проведене ними комплексне експериментальне дослідження пошкоджень мішеней і виявлені прим цьому їх морфологічні ознаки дозволяють об'єктивно і достовірно визначати факт пострілу холостим патроном, оцінювати відстань пострілу, а також проводити диференційну діагностику різних пошкоджень одягу, заподіяних холостими і травматичними патронами в конкретно заданих умовах.

Однак, відомостей щодо морфологічних особливостей часток металів, згорілих і напівзгорілих порошинок, продуктів розкладання ініціюючого вибухового складу капсуля при пострілах із 9 мм патронів не достатньо. Вони потребують грунтовного дослідження та систематизації.

Мета дослідження - дослідити морфологічні особливості часток металів, згорілих і напівзгорілих порошинок, продуктів розкладання ініціюючого вибухового складу капсуля при пострілах із 9 мм пістолетних патронів під растровим скануючим електронним мікроскопом.

Матеріал і методи дослідження. Об’єктами дослідження були частки металів, згорілі і напівзгорілі порошинки, продукти розкладання ініціюючого вибухового складу капсуля у складів факторів, що супроводжують постріли патронами 9х18мм ПМ до пістолету «Форт 17» 3 прямокутною формою нарізів ствола. Постріли виконувались над «слідовою доріжкою» (маркованих аркушах білого чистого паперу формату A4, розкладених на підлозі вздовж напрямку пострілу на відстані до 3 м). Було проведено 3 серії пострілів з відстаней 1-3 м у балістичному тирі науково-дослідницького експертно-криміналістичного центру (НДЕКЦ) МВС України в рамках угоди про співпрацю (№273 від 04.10.2006 р.) У кожній серії виконувалось по 5 пострілів. Після закінчення кожної серії пострілів аркуші паперу збирали, а наявні на них часточки пороху збирали в чашки Петрі з маркуванням, у відповідності до маркування аркушів паперу. Після завершення експериментів всі чашки Петрі досліджували під стереомікроскопом МБС у відбитому і прохідному світлі при збільшеннях до 48x.

Дослідження елементного складу продуктів пострілу в об’єктах біологічного і небіологічного походження проводилось у відділенні судово-медичної криміналістики Київського міського клінічного бюро судово-медичної експертизи з використанням рентгенфлуоресцентного спектрального елементного аналізу на спектрометрі «М4 TORNADO» компанії Bruker (Німеччина). Дослідження морфологічних особливостей часток металів, згорілих і напівзгорілих порошинок, продуктів розкладання ініціюючого вибухового складу капсуля при пострілах із 9 мм пістолетів з прямокутною формою нарізів ствола виконувалось за допомогою електронного растрового скануючого мікроскопу «TESCAN Vega 3» 3 приставкою для проведення енерго-дисперсійного рентгенфлуоресцентного спектрального аналізу при збільшеннях 3-7 тис. Дослідження проводилось у лабораторії електронної мікроскопії Київського науково-дослідницького інституту судових експертиз. В роботі були застосовані стандартні методи варіаційної статистики.

\section{РЕЗУЛЬТАТИ ВЛАСНИХ ДОСЛІДЖЕНЬ ТА ЇХ ОБГОВОРЕННЯ}

На «слідовій доріжці» - аркушах білого паперу, розкладених за напрямком проведення пострілу (рис. 1) патронами 9х18мм ПМ з пістолету «Форт 17», який має прямокутну форму нарізів каналу ствола і патронами 9х19мм Парабеллум з пістолету «Глок 19», який має полігональну форму нарізів каналу ствола, були виявлені продукти пострілу (незгорілі порошини, частки металу та продукти розкладання капсульного складу). Отримані з слідової доріжки нашарування (продукти пострілу), фіксовані на двосторонньому вуглецевому скотчі були поміщені на предметні столики в камеру електронного мікроскопа, в робочій камері якого за допомогою вакуумної помпи створювався зверхнизький вакуум. 


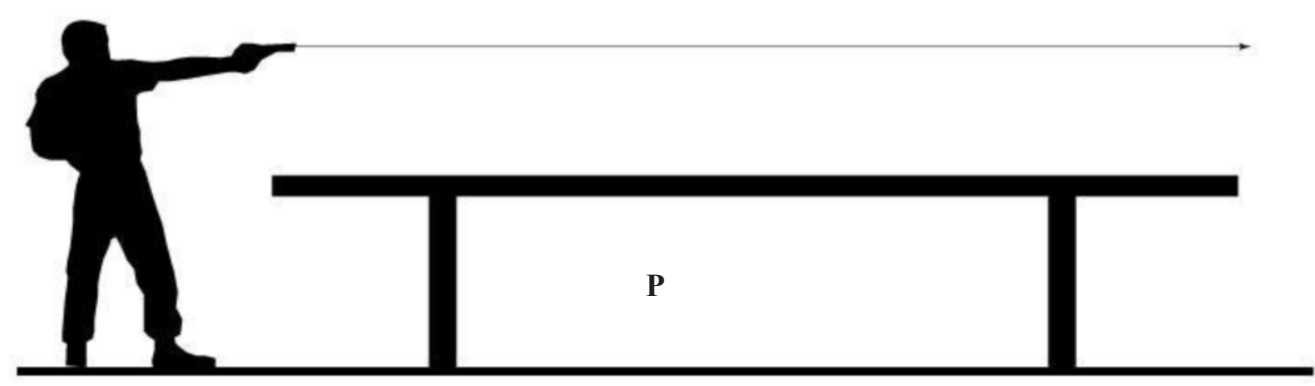

Рис. 1. Схематичне зображення проведення пострілу на «слідову доріжку»

Далі, під час дослідження продуктів пострілу з використанням растрового скануючого електронного мікроскопа «TESCAN Vega 3» були виявлені порошинки, відмінні перш за все за своїм забарвленням: жовтого і сірого кольорів (рис. 2).

3 метою дослідження особливостей поверхні виявлених порошин, а також встановлення морфологічних ознак, через які порошинки після проведення пострілу набувають різного - сірого і жовтого кольору, було проведене дослідження зразків часток незгорілих порошин за допомогою растрового скануючого електронного мікроскопу «TESCAN Vega 3» в режимах SE та BSE.

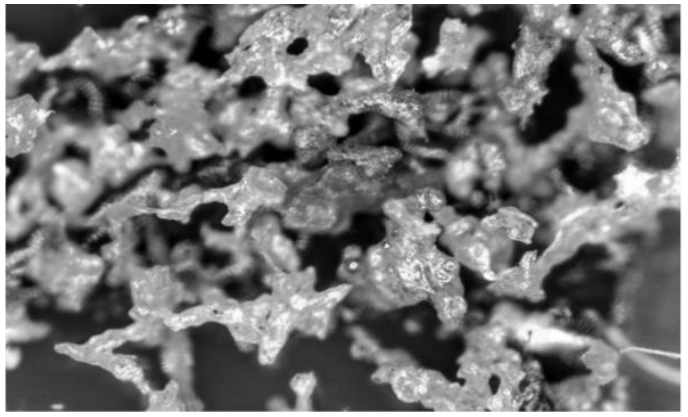

Рис. 2. Зовнішній вигляд порошинок жовтого і сірого кольору (вказані стрілками), що були

виявлені на «слідовій доріжці» при пострілах патроном 9х18мм ПМ (а) та 9х19мм Парабеллум (б). 3б. 124Х:

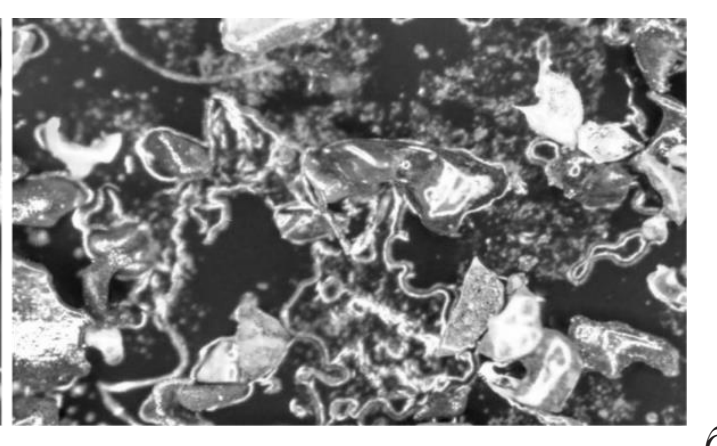

6

Застосований нами растровий скануючий електронний мікроскоп «TESCAN Vega 3» також оснащений приставкою для енергодисперсійного рентгенфлуресцентного спектрального аналізу (EDX), за допомогою якого нами був встановлений елементний склад в обраних ділянках. Режим роботи растрового скануючого електронного мікроскопу BSE дозволяє отримати зображення об'єктів дослідження з розподілом в чорно-сіро-білих тонах (від чорного до білого) в залежності від щільності матеріалу, яка зумовлена атомною масою елементів, 3 яких складається об’єкт дослідження. При збільшенні об'єкту дослідження (незгорілі порошини) виявлено, що порошини мають нерівний рельєф поверхні та вигляд дрібнопухирчастої піни або губки, завдяки наявності на протязі усієї поверхні порошини чисельних кратероподібних заглиблень різних розмірів (рис. 3 ).

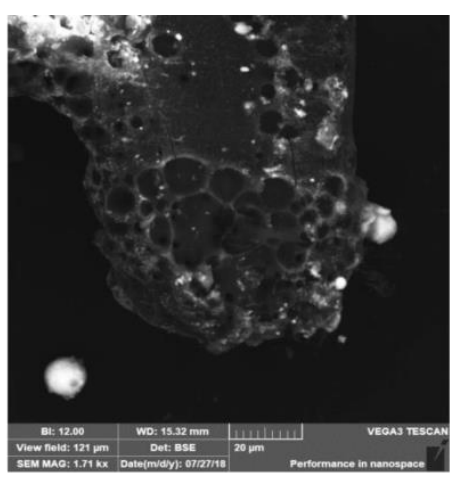

Рис. 3. Зовнішній вигляд поверхні порошинки і накладання продуктів розкладання капсульного складу, що утворились при пострілі патронами 9х18мм ПМ до пістолету «Форт 17». РСЕМ. 3б.: 1700. 
Виявлені за допомогою РСЕМ часточки капсульного складу білого кольору (з вмістом $\mathrm{Pb}, \mathrm{Cu}, \mathrm{Ba})$ за розмірами були розділені на три види: крупні (більше 30 мкм), середні (20-30 мкм) і дрібні (менше 10 мкм). Причому, крупні також були розділені на два види: 1) ті, що піддалися термічній дії і 2) ті, що не піддалися термічній дії (рис. 4).


$\sigma$

Рис. 4. Зовнішній вигляд поверхні дрібної (а) часточки розкладання капсульного складу при пострілі патронами 9х18мм ПМ та спектр (б) вказаної частки. РСЕМ. 3б.: 805.

Крупні часточки капсульного складу (більше 30 мкм), що піддалися термічній дії, мали гострі, рівні краї, 3 хвильовими лініями та напливами рельєфу на поверхні (які є відбитками поверхні ковпачка капсуля при заливанні маси капсульного складу, що ініціює постріл).
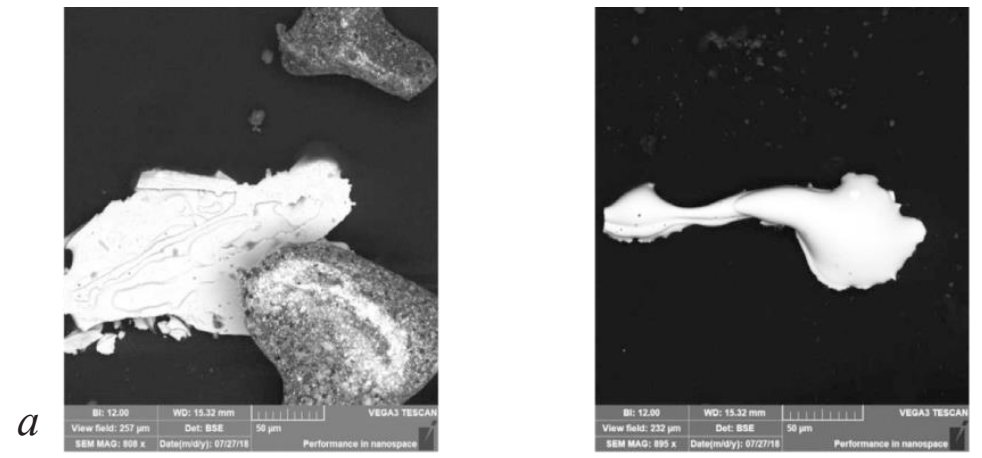

$\sigma$

Рис. 5. Зовнішній вигляд крупних часток капсульного складу: а) неініційований капсульний склад та б) крупна частка капсульного складу, яка піддавалася термічній дії при пострілі патроном 9х18мм ПМ. РСЕМ. Зб.: 808.

Часточки капсульного складу, що піддалися термічній дії і розкладанню при пострілах патронами, мали гладенькі закруглені краї, рівний рельєф поверхні (рис. 5 а,б). До їх складу входили переважно елементи барію(Ва), свинцю(Рb) і сурми $\mathrm{Sb}$ (рис. 5 в).

Як відомо, при проходженні через канал ствола зброї бойовою гранню його нарізів зрізується тонкий шар томпакового покриття куль. При цьому процесі і утворюються металеві частки смугастої форми. Однак, враховуючи різну форму нарізів каналів ствола пістолетів «Форт 17» та «Glok-19» частки металів за морфологічними ознаками відрізнялись. Так, при пострілах з пістолету «Форт 17», канал ствола якого має шість нарізів прямокутної форми, з відстаней 1 і 2 метрів утворювались часточки металу оболонки кулі, що на картах розподілу хімічних елементів (рентгенфлуорисцентний спектральний аналіз) мали вигляд тонких звивистих довгастих та коротких смужок (рис. 6.а). Довжина найбільших смужок коливалась в діапазоні 1,5-2,5 мм.


Рис. 6. Зовнішній вигляд часточок металу у вигляді лусочок, що утворились від дії бойової грані нарізу каналу ствола зброї з прямокутною (пістолет «Форт 17») полігональною (пістолет «Glock 19») формою каналів ствола на відстані 2 м від дульного зрізу зброї. РФСА. 
На відміну від цього, у складі продуктів пострілу пістолетом «Glock 19», часточки металу мали вигляд дрібних кутоподібних лусочок з розмірами до 1 мм (рис. 6 б).

3 використанням растрової скануючої електронної мікроскопії також були виявленні та дослідженні металеві часточки (смужки), що утворилась з поверхні томпакового шару біметалевих оболонкових куль, якими були спорядженні патрони. При значному збільшенні під час пострілу (рис. 7 а), були виявлені борозни та валки, що слідували паралельно один одному і почергово змінювалися (рис. 7 б, в).



$a$
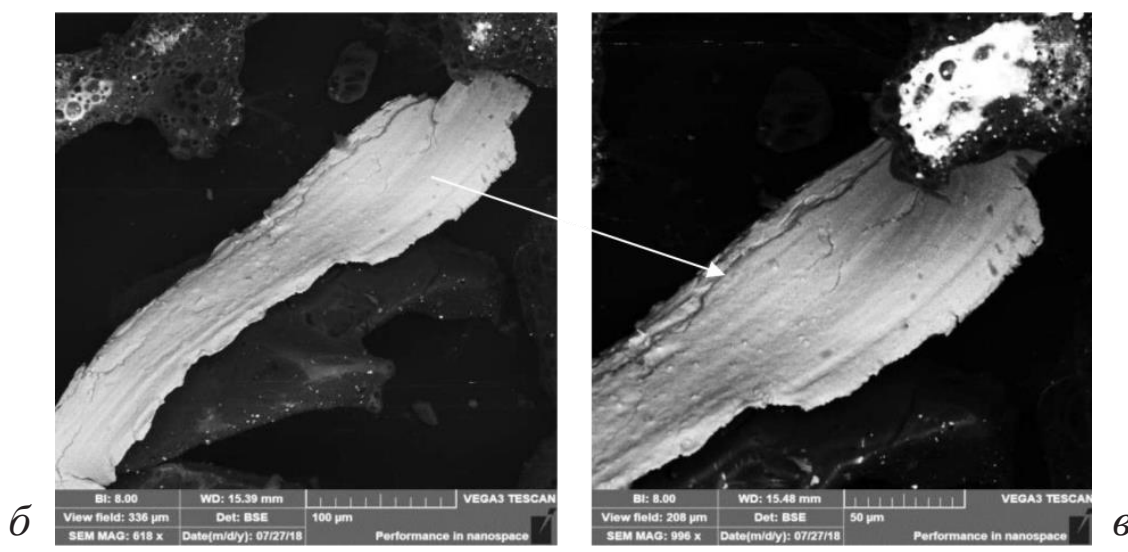

Рис. 7. Зовнішній вигляд металевої часточки (1) і порошинок (2), що утворились при пострілі патроном 9х18мм ПМ з пістолету «Форт 17», який має прямокутну форму нарізів каналу ствола, на відстані 1 м від дульного зрізу зброї. РСЕМ. 3б.: а - 185, б - 618, в - 996.

Вказані елементи є зонами відриву матеріалу оболонки кулі при різанні бойової гранню нарізу каналу ствола зброї.

Окрім цього, нами були виявлені часточки металу, що відрізнялись за кольором завдяки різниці в атомній масі. При великій атомній масі вони набували темних відтінків (чорного кольору), а при низькій - світлих (білого кольору). Так, зокрема часточки $з$ вмістом свинцю $(\mathrm{Pb})$ були білого кольору, а часточки з вмістом міді і цинку $(\mathrm{Cu}, \mathrm{Zn})-$ темно-сірого.

На рис. 8 показані часточки металевої корозії (Fe) і положення часточки металу білого кольору з $\mathrm{Pb}$ на

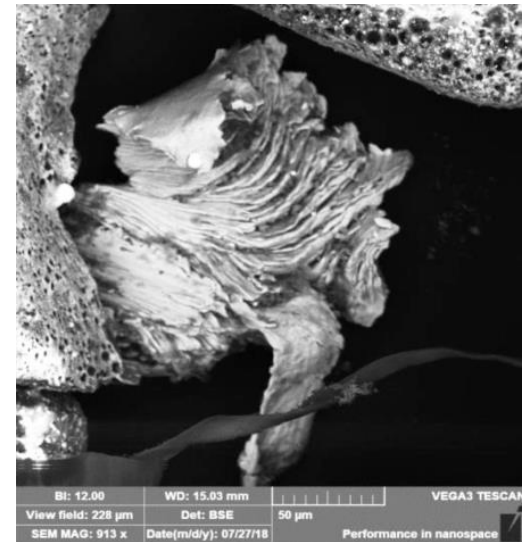
поверхні порошинки.

Отже, наявність продуктів розкладання капсульного складу на поверхні порошинок і металевих смужок свідчить про вогнепальний спосіб метання снаряду, тобто - порошинки і часточки металу утворились при проведенні пострілу.

Рис. 8. Зовнішній вигляд часточки корозії (окис заліза) (1) і порошинки навколо неї (2), які були виявлені на «слідовій доріжці» після пострілу патронам 9х18мм ПМ. а - часточки металевої корозії (Fe), б - часточки металу білого кольору з $\mathrm{Pb}$ на поверхні порошинки (в). PCEM. 3б.: x 913. 


\section{ВИСНОВКИ}

1. Проведене дослідження надає можливість диференціювати штучно спалені порошинки з їх подальшим нанесенням на поверхню ділянки вогнепального ушкодження (пошкодження) з тими порошинками, що утворились при проведенні пострілу із вогнепальної зброї з близької дистанції.

2. Ті порошинки, що мають нашарування білого кольору в максимальній кількості, візуально набувають сірого забарвлення за рахунок нашарування білих поодиноких і дрібних порошинок.

3. Колір кіптяви визначає капсульний склад продуктів пострілу. Сірі порошинки розташовані ближче до запального отвору гільзи і вони максимально вкриті капсульним складом, що розкладається при його вибуху та підпалюванні порохового заряду. Жовті порошинки розташовуються ближче до кулі, причому, на їх поверхні продуктів розкладання капсульного складу вкрай мало, що не змінює колір порошинок, на які діяло полум'я (термічна дія).

\section{Література}

1. Филипчук ОВ, Коваленко ЮН. К методике определения следов металлов методом цветных отпечатков. Судебно-медицинская экспертиза. 1983;3:47.

2. Ануфриев МВ, Бачурин ЛВ, Мокроусов АА, Одиночкина ТФ, Симонов МД, Сорокин ВИ. Выявление продуктов выстрела на руках и одежде проверяемых лиц с целью установления факта производства ими стрельбы: методические рекомендации. Москва: ЭКЦ МВД России; 1999. 33 с.

3. Харин ГМ, Губеева ЕГ, Александров ВН, Осин ЮН. Ультраструктурная характеристика остатков порохового заряда при судебно-медицинском исследовании огнестрельных пулевых повреждений. Судебно-медицинская экспертиза. 2008;3:6-8.

4. Губеева ЕГ, Харин ГМ. Микрозондовый рентгеноспектральный анализ элементного состава поверхности частиц пороха при судебно-медицинском исследовании огнестрельных пулевых повреждений. Судебная экспертиза. 2008;2:113-6.

5. Губеева ЕГ. Анализ несгоревших остатков порохового метательного заряда при судебно-медицинской экспертизе огнестрельных повреждений [диссертация]. Москва; 2009. 145 с.

6. Колкутин ВВ, Макаров ИЮ, Куценко КИ. Характеристика повреждений, причиняемых «холостыми» выстрелами. Судебно-медицинская экспертиза. 2011;3:28-31.

7. Куценко КИ, Макаров ИЮ. Возможности судебно-медицинской оценки повреждений одежды, причиненных холостым выстрелом из пистолета МР-79-9ТМ. Судебно-медицинская экспертиза. 2013;2:7-11.

8. Куценко КИ. Судебно-медицинская характеристика повреждений, причиненных выстрелами холостыми патронами из пистолета МР-79-9ТМ [диссертация]. Москва; 2013. 142 с.

\section{References:}

1. Filipchuk OV, Kovalenko YuN. K metodike opredeleniya sledov metallov metodom tsvetnykh otpechatkov [To the method for determining trace metals by the method of color prints]. Sudebno-meditsinskaya ekspertiza. 1983;3:47. (in Russian)

2. Anufriev MV, Bachurin LV, Mokrousov AA, Odinochkina TF, Simonov MD, Sorokin VI. Vyyavlenie produktov vystrela na rukakh i odezhde proveryaemykh lits s tsel'yu ustanovleniya fakta proizvodstva imi strel'by: metodicheskie rekomendatsii [Identification of products of a shot on the hands and clothes of inspected persons in order to establish the fact of their shooting]. Moskva: EKTs MVD Rossii; 1999. 33 s. (in Russian)

3. Kharin GM, Gubeeva EG, Aleksandrov VN, Osin YuN. Ul'trastrukturnaya kharakteristika ostatkov porokhovogo zaryada pri sudebno-meditsinskom issledovanii ognestrel'nykh pulevykh povrezhdeniy [Ultrastructural characteristics of the remains of the powder charge in the forensic study of gunshot bullet damage]. Sudebnomeditsinskaya ekspertiza. 2008;3:6-8. (in Russian)

4. Gubeeva EG, Kharin GM. Mikrozondovyy rentgenospektral'nyy analiz elementnogo sostava poverkhnosti chastits porokha pri sudebno-meditsinskom issledovanii ognestrel'nykh pulevykh povrezhdeniy [Microprobe xray spectral analysis of the elemental composition of the surface of the powder particles in a forensic study of gunshot bullet damage]. Sudebnaya ekspertiza. 2008;2:113-6. (in Russian)

5. Gubeeva EG. Analiz nesgorevshikh ostatkov porokhovogo metatel'nogo zaryada pri sudebno-meditsinskoy ekspertize ognestrel'nykh povrezhdeniy [Analysis of unburned residues of propellant propellant charge during forensic examination of gunshot injuries] [dissertation]. Moskva; 2009. 145 s. (in Russian)

6. Kolkutin VV, Makarov IYu, Kutsenko KI. Kharakteristika povrezhdeniy, prichinyaemykh «kholostymi» vystrelami [Characteristic of injuries inflicted by a blank gunshot]. Sudebno-meditsinskaya ekspertiza. 2011;3:2831. (in Russian)

7. Kutsenko KI, Makarov IYu. Vozmozhnosti sudebno-meditsinskoy otsenki povrezhdeniy odezhdy, prichinennykh kholostym vystrelom iz pistoleta MR-79-9TM [The possibility of forensic medical assessment of the damage to clothes caused by a blank shots with the MP-79-9TM pistol]. Sudebno-meditsinskaya ekspertiza. 2013;2:7-11. (in Russian) 
8. Kutsenko KI. Sudebno-meditsinskaya kharakteristika povrezhdeniy, prichinennykh vystrelami kholostymi patronami iz pistoleta MR-79-9TM [Forensic characteristics of injuries caused by blank shots from an MP-799TM pistol] [dissertation]. Moskva; 2013. 142 s. (in Russian)

\title{
ОПРЕДЕЛЕНИЕ МОРФОЛОГИЧЕСКИХ ОСОБЕННОСТЕЙ ЧАСТИЦ МЕТАЛЛОВ, СГОРЕВШИХ И ПОЛУСГОРЕВШИХ ПОРОШИНОК, ПРОДУКТОВ РАЗЛОЖЕНИЯ ИНИЦИИРУЮЩЕГО ВЗРЫВНОГО СОСТАВА КАПСЮЛЯ ПРИ ВЫСТРЕЛАХ ИЗ 9 ММ ПИСТОЛЕТОВ С ПРЯМОУГОЛЬНОЙ И ПОЛИГОНАЛЬНОЙ ФОРМАМИ НАРЕЗОВ СТВОЛА С ИСПОЛЬЗОВАНИЕМ РАСТРОВОЙ СКАНИРУЮЩЕЙ ЭЛЕКТРОННОЙ МИКРОСКОПИИ
}

\section{Чихман Я.В.}

Резюме. В работе приведены результаты экспериментального исследования с использованием растровой сканирующей электронной микроскопии морфологических особенностей частиц металлов, сгоревших и полусгоревших порошинок, продуктов разложения инициирующего взрывного состава капсюля при выстрелах 9-мм патронами к пистолету «Форт 17» с прямоугольной и «Glok 19» полигональной формами нарезов ствола. Проведенное исследование дает возможность четко визуализировать выявленные с помощью рентгенфлуоресцентго спектрального анализа частицы металла, образующиеся при движении пули по каналу ствола оружия; дифференцировать сожженые порошинки с их последующим нанесением на поверхность участка огнестрельного повреждения (повреждения) с теми порошинками, которые образовались при проведении выстрела из огнестрельного оружия с близкой дистанции. Также установлено, что цвет копоти определяет капсульный состав продуктов выстрела: серые порошинки расположены ближе к зажигательному отверстию гильзы и они максимально покрытые капсульным составом, который разлагается при его взрыве и поджигании порохового заряда. Желтые порошинки располагаются ближе к руле, причем, на их поверхности продуктов разложения капсульного состава крайне мало, что не меняет цвет порошинок, на которые действовало пламя (термическое действие).

Ключевые слова: судебно-медицинская экспертиза, факторы, сопровождающие выстрел, растровая сканирующая электронная микроскопия.

\section{PRIMER IN THE SHOTS OF 9 MM PISTOLS WITH RECTANGULAR SHAPES AND POLYGONAL RIFLING USING RASTER SCANNING ELECTRON MICROSCOPY}

\author{
Chykmann Ya.
}

Summary. The paper presents the results of an experimental study using scanning scanning electron microscopy of morphological features of metal particles, burnt and semi-burnt powders, decomposition products of the initiating explosive composition of the capsule when fired with 9-mm cartridges for the gun «Fort 17 «with rectangular and» Glok 19 «polygonal shapes of the barrel cuts. The study makes it possible to clearly visualize the metal particles detected by x-ray fluorescence spectral analysis, formed during the movement of the bullet through the barrel of the weapon; to differentiate the burned powders with their subsequent drawing on a surface of a site of fire damage (damage) with those powders which were formed when carrying out a shot from firearms from a close distance. It is also established that the color of the soot determines the capsule composition of the products of the shot: gray powders are located closer to the incendiary opening of the sleeve and they are maximally covered with a capsule composition, which decomposes when it explodes and ignites the powder charge. Yellow powders are located closer to the steering wheel, and on their surface of the decomposition products of the capsule composition is very small, which does not change the color of the powders, which acted on the flame (thermal action).

Keywords: forensic examination, factors accompanying the shot, scanning scanning electron microscopy.

УДК 612.12-001.45:340.624

\section{СИСТЕМАТИЗАЦІЯ ТРАВМУЮЧИХ ЧИННИКІВ ПРИ ПОСТРІЛАХ ЕЛАСТИЧНИМИ КУЛЯМИ 3 ПІСТОЛЕТІВ ТА РЕВОЛЬВЕРІВ, ПРИЗНАЧЕНИХ ДЛЯ САМООБОРОНИ}

\author{
ССухий В.Д. ${ }^{1}$, Мішалов В.Д. ${ }^{2}$, Бачинський В.Т. ${ }^{3}$, Кривда Г.Ф. $^{4}$, Костенко С.Я. $^{5}$ \\ Міністерство оборони України ${ }^{1}$ \\ Національна медична академія післядипломної освіти імені П.Л. Шупика ${ }^{2}$ \\ ДВНЗ «Буковинський державний медичний університет» ${ }^{3}$ \\ ДВНЗ «Одеський національний медичний університет» ${ }^{4}$ \\ Ужгородський національний університет ${ }^{5}$ \\ Резюме. Показано, що при пострілах еластичними кулями 3 пістолетів та револьверів, призначених для
} самооборони, на тіло людини діють такі ж групи травмуючих чинників, як при пострілах 3 вогнестрільної зброї. На 